\title{
ЖЕНЩИНА ВО ФРЕЙМЕ-СЦЕНАРИИ РУССКИХ ПАРЕМИЙ
}

\author{
THE WOMAN IN THE INTERPRETATIVE FRAME \\ OF RUSSIAN PAREMIAS
}

JOANNA OLECHNO-WASILUK

\begin{abstract}
The paper analyses the image of woman in the interpretative frame of Russian paremias. The author asks a number of questions: What role does the woman play in society and family? How is she treated by her husband? How do they treat their children? Who is the woman juxtaposed with? Who is she compared to? Answering these questions the author tries to reconstruct the image of woman functioning in the Russian awareness. This is the image passed from generation to generation in proverbs and sayings, which are the products of language, culture and awareness.
\end{abstract}

Keywords: cognitive linguistics, frame, script, interpretative frame, Russian paremias, concept

Joanna Olechno-Wasiluk, Uniwersytet Warmińsko-Mazurski w Olsztynie, Olsztyn Polska, joanna.olechno-wasiluk@uwm.edu.pl

ORCID ID: 0000-0002-7500-5151

В конце XX века произошел лингвокультурологический бум, когда проблемы взаимосвязи языка и культуры вошли в число самых актуальных в современной лингвистике. Этот взрыв интереса к проблеме - результат когнитивной революции в языкознании [Маслова 2001: 75].

Когнитивная лингвистика занимается исследованием ментальных процессов. Одним из ее ключевых понятий является концепт. Концепты рассматриваются как „сложившиеся дискретные единицы (ментальные образы) коллективного сознания”. Каждая концептуальная единица занимает соответствующую ячейку в национально обусловленной „концептосфере" языка [Бабушкин 1996: 95].

Кроме концепта другим ключевым понятием когнитивной лингвистики является понятие фрейма-сценария. В научный обиход этот термин ввел американский исследователь искусственного интеллекта Марвин Ли Минский. Российские языковеды Зинаида Даниловна Попова и Иосиф Абрамович Стернин разделили данное понятие на „фрейм” и „сценарий”. 
Термин „фрейм” был введен в лингвистику Чарльзом Филлмором и изначально понимался как набор слов, каждое из которых обозначает часть целого. В настоящее время в лингвистике существует несколько толкований этого термина.

Фрейм, по Марвину Минскому, это способ организации представлений, хранимых в памяти. Исследователь утверждает, что человек воспринимает и понимает окружающий мир всегда согласно определенной схеме, которая позволяет обрабатывать информацию тем или иным способом. Таким образом, общение оказывается возможным только при наличии в сознании говорящих, в их картине мира, неких смысловых, информационных „сгущений”, т.е. фреймов, с помощью которых человек осознает зрительные образы (фреймы визуальных образов), понимает слова (семантические фреймы), рассуждения, действия (фреймы-сценарии), повествования (фреймы-рассказы) и т.д. [Минский 1979]. Минский понимает фрейм как объемный, многокомпонентный концепт, представляющий собой „пакет” информации, „один из способов представления стереотипной ситуации" [1988: 289].

В понимании Анатолия Павловича Бабушкина фрейм - это структура знаний, представляющая собой часть информации об определенном фрагменте человеческого опыта, это совокупность хранимых в памяти ассоциаций [Бабушкин 1996: 25]. Ученый отмечает, что фрейм - это одна из центральных фигур представления знаний [Бабушкин 1996: 24]. Попова и Стернин под фреймом понимают мыслимый в целостности его составных частей многокомпонентный концепт, совокупность стандартных знаний о предмете или явлении [Попова, Стернин 2007: 119].

Термин „фрейм” может обозначать когнитивную основу, общую для большинства когнитивных моделей, при условии кодирования в них представления о тех фрагментах окружающей действительности, которые вкладываются в понятие ситуации [Минский 1988: 289], происшествия [Плешакова 1998: 8] и др.

Второй компонент фрейма-сценария - сценарий. Сценарий во фрейме это когнитивная структура динамического характера, предполагающая последовательную смену этапов, эпизодов. Эти этапы могут быть представлены в виде структуры для декларативного представления знаний о типизированной ситуации, иными словами, в виде фреймов. Сценарий - это динамически представленный фрейм как разворачиваемая во времени определенная последовательность этапов [Болдырев 2000: 37].

По мысли Минского, „сценарий вырабатывается в результате интерпретации текста, когда ключевые слова и идеи текста создают тематиче- 
ские («сценарные») структуры, извлекаемые из памяти на основе стандартных, стереотипных значений” [Минский 1979: 181].

Следующей важной категорией когнитивной лингвистики являются ключевые слова культуры. Чтобы слово стало ключевым словом культуры, оно должно появиться в составе фразеологизмов и пословиц - носителях культурно-национальной информации [Маслова 2001: 63], в которых наиболее ярко выражается культурная память народа. Вероника Николаевна Телия считает, что „фразеологический состав языка играет особую роль в трансляции культурно-национального самосознания народа и его идентификации как такового. Это связано с тем, что в образном содержании единиц фразеологического состава воплощено культурно-национальное мировидение" [Телия 1996: 64].

Валентина Авраамовна Маслова обращает внимание на то, что фразеологизмы отражают в своей семантике длительный процесс развития культуры народа, фиксируют и передают от поколения к поколению культурные установки и стереотипы. Фразеологические единицы всегда обращены на субъект, т.е. они описывают мир и интерпретируют его, оценивают и выражают субъективное отношение к нему [Маслова 2001: 86].

Условия жизни и быта народа, его история, трудовая деятельность и социальные отношения отразились в пословицах и поговорках. Русские пословицы различаются по своему происхождению, по времени возникновения, по тематике. В паремиях отразились разные эпохи, разные общественные отношения.

Многие ключевые слова и концепты в составе пословиц и поговорок являются динамическими образами, поэтому целесообразно рассматривать их как фреймы-сценарии. Вслед за многими исследователями (Николай Николаевич Болдырев, Минский) мы понимаем фрейм-сценарий как когнитивную структуру динамического характера, предполагающую последовательную смену эпизодов. В русле такой методики будем исследовать образ женщины, отраженный в русских паремиях.

Основным критерием отбора материала для настоящего исследования служит наличие в пословицах и поговорках лексемы женщина, а также слов, содержащих сему „женщина”: жена, мать, теща, дочь, вдова, старая дева. Основными источниками материала являются сборник Владимира Ивановича Даля Пословицы русского народа (Москва 1984) и интернет-сайты: Aphorism.Ru, Пословицы и поговорки, Проза.ру, Пословицы: большой сборник пословиц. В данной работе мы проанализировали 82 паремии.

Роджер Шенк и Роберт Абельсон предлагают сравнивать терминалы фрейма-сценария с наиболее типичными вопросами, обычно связанны- 
ми с данной ситуацией, образом или понятием [Высоков 2014]. Чтобы охарактеризовать образ женщины во фрейме-сценарии русских паремий предлагаем поставить следующие вопросы:

1. Какую роль в обществе играет женщина?

2. Каково типичное поведение женщины?

3. Какую женщину мужчина выбирает в жены?

4. Каково отношение мужа к жене?

5. Каково отношение детей к матери и матери к детям?

Ответы на перечисленные вопросы помогут создать образ женщины во фрейме-сценарии, указанный в русских паремиях.

\begin{tabular}{|l|l|}
\hline \multicolumn{2}{|l|}{ 1. Какую роль в обществе выполняет женщина? } \\
\hline жена & $\begin{array}{l}\text { Без жены дом - содом. } \\
\text { Дом с хорошей женой - рай. }\end{array}$ \\
\hline мать & $\begin{array}{l}\text { От солнышка тепло, от матушки добро. } \\
\text { Без матери рой не держится. } \\
\text { Мать всякому делу голова! }\end{array}$ \\
\hline теща & $\begin{array}{l}\text { Жена для совета, теща для привета, а нет милей родной матери. } \\
\text { Не женись на теще, не выходи замуж за свекра. }\end{array}$ \\
\hline вдова & $\begin{array}{l}\text { Лучше молодая вдова, чем старая дева. } \\
\text { На вдове жениться, что старые штаны надевать: не вошь, так гнида. } \\
\text { Вдову взять - спокойнее спать. } \\
\text { Не купи у попа лошади, не бери и у вдовы дочери. }\end{array}$ \\
\hline старая дева & $\begin{array}{l}\text { Старая правда да старое вино - добро, но не старая девка. } \\
\text { Где старая девка живет, вокруг и крапива не растет. } \\
\text { Лучше выйти замуж без любви, чем остаться старой девкой. } \\
\text { Лучше молодая вдова, чем старая дева. }\end{array}$ \\
\hline дочь & $\begin{array}{l}\text { Глядя на мать, бери дочь. } \\
\text { Какова мать, такова и дочь. }\end{array}$ \\
\hline
\end{tabular}

Женщина в паремиях не существует вне семьи. Поэтому социальная роль, социальный статус женщины определяется ее семейным положением. Женщина должна стать женой и матерью, чтобы вести домашнее хозяйство и воспитывать детей. Поэтому в паремиях функционирует презрительное отношение к старым девам. Бытует мнение, что Лучше выитти замуж без ююбви, чем остаться старой девкой, потому что главная задача любой женщины - создать семью, то есть выйти замуж и родить ребенка: Жена без мужа - что дом без крыши. Роль дочери - стать похожей на мать и выполнять те же функции: Глядя на мать, бери дочь. Между женой и старой девой в социальной лестнице занимает место вдова: Лучше молодая вдова, чем старая дева. 


\begin{tabular}{|l|l|}
\hline \multicolumn{2}{|c|}{ 2. Каково типичное поведение женщины? } \\
\hline плачет & Баба слезами беде помогает. \\
Без плачу у бабы дело не спорится. \\
У баб да у пьяных слезы дешевы. Бабьи слезы чем больше унимать, \\
тем хуже. \\
Замуж идет - песни прет, а вышла - слезы льет. \\
Мать плачет, что река льется; жена плачет, что ручей течет; невеста \\
плачет, как роса падет: взойдет солнце, росу высушит.
\end{tabular}

Женщина во фрейме-сценарии паремий это болтливая баба, которая плачет без особой причины. Это лживая девушка, которая обманывает мужа и позорит его перед людьми. Пословицы определяют место женщины: она должна сидеть дома, вести домашнее хозяйство и создавать в нем уют: Бабе дорога - от печи до порога.

\begin{tabular}{|l|l|}
\hline \multicolumn{2}{|l|}{ 3. Какую женщину мужчина выбирает в жены? } \\
\hline $\begin{array}{l}\text { похожую на } \\
\text { мать }\end{array}$ & $\begin{array}{l}\text { Глядя на мать, бери дочь. } \\
\text { Какова мать, такова и дочь. } \\
\text { Первую дочь бери по матери, а вторую - по сестре. }\end{array}$ \\
\hline $\begin{array}{l}\text { моложе } \\
\text { мужчины }\end{array}$ & $\begin{array}{l}\text { Муж молод, жена стара - беда не мала. Жену старую взять - часто } \\
\text { с нею хлопотать. } \\
\text { С годами мед крепчает, а девушка скисает. } \\
\text { Злее нет осенней мухи да девки-вековухи. }\end{array}$ \\
\hline умную & $\begin{array}{l}\text { Выбирай жену не по наряду, а по уму. } \\
\text { На дуре женишья - сам в дураках будешь. } \\
\text { Жену дурную взять - стыдно в люди показать. } \\
\text { Женский ум лучше всяких дум. }\end{array}$ \\
\hline добрую & $\begin{array}{l}\text { Добрую жену взять - ни скуки, ни горя не знать. } \\
\text { Шей шубу теплее, а жену выбирай добрее. }\end{array}$ \\
\hline трудолюбивую & Выбирай жену не в хороводе, а в огороде. \\
\hline
\end{tabular}


О супружестве решает муж. Мужчина выбирает девушку в жены, у женщины нет возможности выбрать мужа. Можно предугадать, какой женой и хозяйкой будет женщина - для этого следует познакомиться с ее матерью. Мужчина сравнивает с ней свою будущую жену. Идеальная супруга должна быть умной, доброй и молодой. Она должна быть хорошей и трудолюбивой хозяйкой. О такой жене мужчины мечтают, но одновременно они еще до женитьбы уверены, что у них будет плохая супруга: Все девушки хороши, но откуда злые жены берутся?

\begin{tabular}{|l|l|}
\hline \multicolumn{2}{|c|}{ 4. Каково отношение мужа к жене? } \\
\hline Не уважает жены, бьет ее. & $\begin{array}{l}\text { Вино пей, жену бей, ничего не бойся. } \\
\text { Бей жену к обеду, к к ужину опять. } \\
\text { Чем больше жену бьешь, тем щи вкуснее } \\
\text { Бабий быт - завсе бит. }\end{array}$ \\
\hline $\begin{array}{l}\text { Стремится подчинить себе } \\
\text { жену. }\end{array}$ & Не муж в мужьях, кем жена владеет. \\
\hline $\begin{array}{l}\text { Пытается доказать, } \\
\text { что она не в состоянии } \\
\text { существовать без него. }\end{array}$ & $\begin{array}{l}\text { Жена без мужа - вдовы хуже. } \\
\text { Жена без мужа, что кобыла без узды. }\end{array}$ \\
\hline
\end{tabular}

Муж относится к жене плохо. Не уважает ее и бьет: Кобыла не лошадь, баба не человек, Бей жену к обеду, а к ужину опять.

Следует отметить, что в паремиях воспевается женщина-мать. Образ матери ассоциируется с другом, ласковым солнышком, со всем, что оценивается как доброе и хорошее. Единственная радость женщины это дети, особенно сын - иногда ею избалованный. Отсюда в языке появилось фразеологическое сочетание Матушкин сынок или Матушкин запазушник.

Трудно переоценить роль матери в воспитании ребенка: Без отци полсироты, а без матери - вся сирота; Сердие матери греет лучше солнца; Ближе матери друга нет, Нет такого дружка, как родимая матушка; При солнышке тепло - при матери добро.

\begin{tabular}{|l|l|}
\hline \multicolumn{2}{|c|}{ 5. Каково отношение детей к матери и матери к детям? } \\
\hline Мать любит своих детей & Никто так детям не верит, как мать родная. \\
беззаветно. & Ради деток мать готова себя продать. \\
Мать с детьми сильно & У сына заболит пальчик, а у матери - сердце. \\
связана. & Матушкин сынок, а батюшкин горбок. \\
Матери особо привязаны & Мать при сыне не наследница. \\
к сыновьям. & Счастливая дочь - в отца, а сын - в мать. \\
\hline
\end{tabular}




\begin{tabular}{|l|l|}
\hline $\begin{array}{l}\text { Матери посвящают свою } \\
\text { жизнь детям }\end{array}$ & Мать при детях, что птица в клетке. \\
\hline $\begin{array}{l}\text { Мать несет } \\
\text { ответственность за } \\
\text { воспитание и развитие } \\
\text { детей. }\end{array}$ & Какова матка, таковы и детки. \\
\hline Мать гладит ребенка. & $\begin{array}{l}\text { Мать гладит по шерсти, а мачеха - насупротив. } \\
\text { Мать и бьет, так гладит, а чужая и гладит, так бьет. }\end{array}$ \\
\hline $\begin{array}{l}\text { Бывает, что мать бьет } \\
\text { своих детей. }\end{array}$ & $\begin{array}{l}\text { Мать высоко замахивается, да не больно бьет. } \\
\text { Материны побои не больны. } \\
\text { Мать и бьет, так гладит, а чужая и гладит, так бьет. }\end{array}$ \\
\hline
\end{tabular}

Следует отметить, что в большинстве приведенных нами паремий образ женщины статичен. Ее роль в пословицах и поговороках сводится к одному: она ограничена семьей. Самым многоаспектным и разносторонним образом является образ жены. В нем сочетается как положительное, так и негативное отношение мужчины к женщине. С одной стороны она - счастье семьи, опора мужа, без которой мужчина слаб (Дом с хорошей женой - рай; У хорошей жены и плохой муж будет молодиом), с другой стороны муж относится к супруге как к рабыне: Чем больще жену бъешъ, тем щи вкуснее.

На образ женщины во фрейме-сценарии повлияло достаточно длительное существование патриархального общества. Эту патриархальность замечаем и в пословицах: Мое дело сторона, а муж прав; Мужнин грех за порогом остается, а жена все домой несет. Многие русские пословицы задают определенный социальный статус женщины - она низшее создание, над которым мужчина утверждает свою власть и доминирование.

В образе женщины во фрейме-сценарии наиболее яркими когнитивными признаками оказались ее характеристики, связанные с заботой о ближних, о семье, которые составляют ядро данного концепта и свидетельствуют о наиболее значимых для современного русского сознания качествах, присущих женщине. В паремиях воспевается женщина-мать.

Следует подчеркнуть, что народные пословицы и поговорки отражают прежде всего архаическую крестьянскую культуру. Образ женщины представляет собой проекцию стереотипных представлений о ней как носителе социально предписанных качеств и свойств, сформировавшихся на основе функций, выполняемых женщиной в обществе. 


\section{Библиография}

Бабушкин А. П. 1996. Типы концептов в лексико-фразеологической семантике языка, Воронеж: Издательство Воронежского государственного университета.

Болдырев Н. Н. 2000. Когнитивная семантика, Тамбов: Издательский дом ТГУ им. Г.Р. Державина.

Высоков И. Е. 2014. Психология познания: учебник для бакалавриата и магистратуры, Москва: Юрайт, электронный ресурс: https://studme.org/47251/psihologiya/ skripty_plany_tseli (доступ 22.07.2017).

Даль В. И. 1984. Пословищы русского народа, Москва: Художественная литература.

Караулов Ю. Н., Черкасова Г. А., Уфимцева Н. В., Сорокин Ю. А., Тарасов Е. Ф. 2002. Русский ассоциативный словарь, т. 1, Москва: Астрель, АСТ.

Леонтьев А. А. 1969. Язык, речь, речевая деятельность, Москва: Просвещение.

Леонтьев А. А. 1993. Языковое сознание и образ мира. Язык и сознание: парадоксальная реальность, Москва: Институт языкознания РАН.

Маслова В. А. 2001. Лингвокультурология, Москва: Академия.

Минский М. 1979. Фреймы для представления знаний, Москва: Энергия.

Минский М. 1988. Остроумие и логика когнитивного бессознательного, [в:] Новое $b$ зарубежной лингвистике, вып. ХХІІІ: Когнитивные аспекты языка, Москва: Прогресс.

Плешакова А. В. 1988. „Исследование фреймов «происшествие» на материале русских и английских газетных текстов жанра «Информационное сообщение»", автореф. дисс. канд. филол. наук, Саратов (на правах рукописи).

Попова 3.Д., Стернин И.А. 2007. Когнитивная минвистика, [в:] 3. Д. Попова, И. А. Стернин (ред.), Лингвистика и межкультурная коммуникация, Москва: АСТ: Восток - Запад.

Телия В. Н. 1996. Русская фразеология. Семантический, прагматический и лингвокультурологический аспекты, Москва: Школа „Языки русской культуры”.

Филлмор Ч. 1988. Фреймы и семантика понимания, [в:] Новое в зарубежной лингвистике, вып. XXIII, Москва: Прогресс.

\section{Интернет-источники}

Aphorism.Ru, электронный peсурс: http:/ / www.aphorism.ru/dal (доступ 22.07.2017)

Пословицы: большой сборник пословии, электронный ресурс: http://poslovicy-pogovor ki.ru/index/o_zhene/0-85 (доступ 22.07.2017).

Пословицы и поговорки, электронный ресурс: http:/ / posloviz.ru/category/semya-muzhzhena/page2.html (доступ 22.07.2017).

Проза.py, электронный ресурс: https://www.proza.ru/2009/03/19/1124 (доступ 22.07.2017). 